\title{
Penyuluhan Hak Asasi Manusia dalam Mendorong Budaya Sadar Hukum di SMAN 5 Bandar Lampung
}

\author{
Malicia Evendia*, Ade Arif Firmansyah
}

IImu Hukum, Universitas Lampung, Bandar Lampung, 35145, Lampung, Indonesia

\begin{abstract}
Abstrak.
Kegiatan Pengabdian Kepada Masyarakat ini bertujuan untuk meningkatkan kesadaran hukum masyarakat khususnya generasi muda dalam memahami Hak Asasi Manusia diri sendiri dan pentingnya menghargai Hak Asasi Manusia orang lain dalam kerangka negara hukum. Hal ini penting agar para siswa/i tidak hanya melaungkan Hak Asasi Manusia yang melekat pada diri sendiri, namun mengabaikan Hak Asasi Manusia yang juga melekat pada orang lain. Adapun target khusus kegiatan ini harapannya menjadi sebuah solusi dan upaya dalam mendorong budaya sadar hukum agar semakin terciptanya kondisi taat dan tertib hukum di kalangan muda. Metode yang digunakan dalam kegiatan ini yaitu melalui ceramah dan diskusi. Adapun sasaran khalayak kegiatan ini yaitu Siswa/i kelas X SMA N 5 Bandar Lampung. Hasil dari kegiatan pengabdian ini menunjukan bahwa kesadaran hukum dan pemahaman peserta terhadap Hak Asasi Manusia telah meningkat hingga $80 \%$. Hal ini ditunjukkan dengan beberapa indikator diantaranya: peningkatan pengetahuan terkait dasar hukum Hak Asasi Manusia, konsep dan manfaat budaya sadar hukum, produk hukum daerah yang telah ada dalam upaya perlindungan Hak Asasi Manusia, serta kepedulian dalam ikut berkontribusi memikirkan upaya yang pemerintah dapat lakukan dalam rangka meningkakan budaya sadar hukum dikalangan muda agar lebih baik.
\end{abstract}

Kata kunci.

HAM; Sadar Hukum; Penyuluhan.

\section{PENDAHULUAN}

Era keterbukaan informasi dan kebebasan pers yang terjadi saat ini, telah membuka mata masyarakat tentang betapa banyaknya pekerjaan rumah yang masih harus dibenahi dibidang penyadaran dan penegakkan hukum di negara ini. Setiap hari, selalu ada saja media yang memberitakan tentang berbagai kejadian pelanggaran hukum seperti kasus kekerasan, tawuran pelajar, bentrokan antar warga di beberapa daerah, ketidakpuasan terhadap hasil pilkada, perebutan lahan pertanian maupun tambang, perjudian, korupsi, dan lain-lain.

Pergeseran kekuasaan ke daerah (otonomi daerah) sesungguhnya juga berimbas pada

* Corresponding author: maliciaevendia@gmail.com

Received 18 November 2020; Received in revised form 28 November 2020; Accepted 9 December 2020 Available online 24 December 2020

Lembaga Penelitian dan Pengabdian Kepada Masyarakat

Universitas Lampung 
semakin kuatnya kewenangan pemerintah daerah (Pemda) untuk menegaskan penghormatan, perlindungan dan pemenuhan Hak Asasi Manusia (HAM). Namun layaknya dua sisi mata uang, dapat pula berakibat pada semakin tingginya potensi pelanggaran HAM. Data pengaduan Komnas HAM telah membuktikan, bahwa selama kurang lebih 5 tahun terakhir, Pemda selalu menempati tiga besar pihak yang paling banyak diadukan melakukan tindakan yang terindikasi pelanggaran HAM [1].

Membicarakan HAM berarti membicarakan dimensi kehidupan manusia. HAM, ada bukan karena diberikan oleh masyarakat dan kebaikan dari negara, melainkan berdasarkan martabatnya sebagai manusia [2]. HAM merupakan hak yang melekat dengan kuat di dalam diri manusia. Keberadaannya diyakini sebagai bagian yang tak terpisahkan dari kehidupan manusia. Wacana HAM bukanlah berarti menafikan eksistensi hak-hak asasi manusia yang sebelumnya memang telah diakuii oleh manusia itu sendiri secara universal [3]. Secara aturan konstitusi Indonesia, pada Pasal 28 UUD 1945 telah diatur bahwa setiap warga negara harus menjaga HAM. HAM selain diatur dalam konsitusi yaitu UUD 1945, juga diatur dalam Undang-Undang Nomor 39 Tahun 1999 tentang Hak Asasi Manusia.

Amat penting untuk menghargai hak asasi setiap manusia, sehingga setara. HAM juga sudah dibedakan antara hak dan apa kewajiban setiap orang, melaksanakan hak harus sesuai dengan hukum yang berlaku. Fungsi hukum bukan hanya menjaga ketertiban hukum, namun dapat menjadi alat dalam melakukan perubahan sosial, yakni mendorong perubahan dengan mengubah relasi atau pola-pola hubungan di dalam suatu masyarakat, menjadi lebih baik dan berkeadilan.

Membina kesadaran hukum adalah suatu tuntutan pembaharuan sosial yang dewasa ini menjadi perhatian pemerintah dan mulai digalakan dalam berbagai usaha pembangunan. Melalui Peraturan Presiden No. 5 Tahun 2010 tentang Rencana Pembangunan Jangka Menengah, pemerintah telah menetapkan arah kebijakan untuk memperbaiki substansi (materi) hukum, struktur (kelembagaan) hukum, dan kultur (budaya hukum) melalui berbagai upaya.

Pelaksanaan HAM di Indonesia perlu mempertimbangkan realitas nilai-nilai adat istiadat, budaya, dan agama. Selain itu, karena dipandang upaya diseminasi HAM masih berjalan lamban, maka dibutuhkan suatu langkah akseleratif. Saat ini Indonesia telah menetapkan Rencana Aksi Nasional HAM (Ranham) Indonesia berdasarkan Peraturan Presiden Nomor 75 Tahun 2015 tentang Rencana Aksi Nasional Hak Asasi Manusia Tahun 2015-2019, sebagaimana telah diubah dengan Peraturan Presiden Nomor 33 Tahun 2018. Salah satu strategi implementasi Ranham berdasarkan peraturan tersebut yaitu "Pendidikan dan peningkatan kesadaran masyarakat tentang HAM".

Perbincangan tentang masalah "budaya hukum" saat ini menjadi penting. Budaya hukum merupakan salah satu komponen yang sangat menentukan apakah substansi hukum maupun tatanan proseduralnya diterima oleh masyarakat dimana hukum itu diterapkan atau ditegakan.Oleh karenanya Lawrence M. Friedman menegaskan bahwa "komponen budaya merupakan motor penggerak bagi sebuah tatanan hukum" [4].

Kesadaran hukum adalah kesadaran diri sendiri tanpa tekanan, paksaan, atau perintah dari luar untuk tunduk pada hukum yang berlaku. Kesadaran hukum itu bukanlah sematamata sesuatu yang tumbuh secara spontan dalam hati sanubari masyarakat, akan tetapi ia juga merupakan sesuatu yang harus dipupuk secara sadar, agar dapat tumbuh dalam hati sanubari masyarakat. Von Savigny menjelaskan hal ini dengan mengatakan, isn und wird mit dem volke.

Budaya sadar hukum menjadi sebuah kebutuhan dalam penerapan dan penegakan hukum, sehingga tujuan hukum dapat tercapai. Hukum sebagai sebuah sistem, harus mampu mensinergikan seluruh komponennya, yaitu struktur hukum, substansi hukum dan budaya hukum. Selain itu pentingnya budaya hukum saat ini, yaitu untuk menyikapi kondisi sosial-politik yang memprinhatikan dengan menguatnya sikap intoleransi yang berpotensi merusak kebhinekaan dan mengikis solidaritas warga sebagai sebuah bangsa.

Kondisi inilah yang menjadi pertimbangan khusus untuk dilaksanakan Pengabdian 
Kepada Masyarakat melalui Penyuluhan Hak Asasi Manusia dalam Mendorong Budaya Sadar Hukum di SMA N 5 Bandar Lampung. menjadi sebuah kebutuhan karena masih rendahnya kesadaran hukum masyarakat khususnya generasi muda, perlu ada upaya yang berkesinambungan. Dengan demikian, kegiatan pengabdian ini layak dan urgen untuk dapat dijalankan.

\section{BAHAN DAN METODE}

\section{Bahan}

Lahirnya TAP MPR-RI Nomor XVII /MPR/1998 tentang Hak Asasi Manusia di awal-awal reformasi menandakan, bahwa Hak Asasi Manusia merupakan salah satu pilar penting, di samping pemberantasan korupsi. TAP MPR tersebut mengamanatkan agar Lembagalembaga Tinggi Negara dan seluruh Aparatur Pemerintah untuk menghormati, menegakkan dan menyebarluaskan pemahaman mengenai hak asasi manusia kepada seluruh masyarakat (Lihat Pasal 1 TAP MPR No XVII/ MPR/1998). Dalam Pasal 2, TAP MPR tersebut juga Menugaskan Presiden dan DPR untuk meratifikasi berbagai instrumen PBB tentang Hak asasi Manusia, sepanjang tidak bertentangan dengan Pancasila dan UUD 1945.

Sebagai pelaksanaan dari amanat tersebut, pada tahun 1999 lahir UU Nomor 39 Tahun 1999 tentang Hak Asasi Manusia. Kemudian melalui Amandemen Kedua UUD 1945, hakhak asasi manusia ditambahkan ke dalam Pasal 28 UUD 1945. Pada tahun 2005, Indonesia mengikatkan diri pada dua instrumen internasional, yang penting bagi hak asasi manusia, yaitu meratifikasi Kovenan Hakhak Sipil dan Politik (melalui UU Nomor 12 Tahun 2005) dan Kovenan Hak-hak Ekonomi, Sosial dan Budaya (melalui UU Nomor 11 Tahun 2005).

Selain instrumen-instrumen hukum di atas, lahir juga sejumlah peraturan perundangundangan, yang secara khusus, mengatur bidang-bidang tertentu hak asasi manusia. Antara lain: Undang-Undang Nomor 23 Tahun 2003 tentang Perlindungan Anak; UndangUndang Nomor 23 Tahun 2004 tentang Penghapusan Kekerasan Dalam Rumah Tangga; UndangUndang Nomor 11 Tahun 2009 tentang Kesejahteraan Sosial; UndangUndang 19 Tahun 2011 tentang Pengesahan Convention on The Rights of Persons with Disabilities (Konvensi tentang Hak-Hak Penyandang Disabilitas); dan lain sebagainya.

Dalam hukum Indonesia, hak asasi manusia diartikan sebagai seperangkat hak, yang melekat pada hakikat dan keberadaan manusia, sebagai mahkluk Tuhan Yang Maha Esa dan merupakan anugerah-Nya, yang wajib dihormati, dijunjung tinggi dan dilindungi oleh negara, hukum, Pemerintah, dan setiap orang, demi kehormatan serta perlindungan harkat dan martabat manusia. Hak Asasi Manusia merupakan hak yang melekat pada diri manusia yang bersifat kodrati dan fundamental, yang harus dihormati, dipenuhi, dilindungi, ditegakkan dan dimajukan bersama baik oleh individu, pemerintah, dan negara. Hal ini juga tidak terlepas bahwa HAM merupakan hak dasar setiap manusia yang penting dalam mewujudkan kesejahteraan masyarakat.

Hak asasi adalah hak-hak yang dimiliki manusia semata-mata karena ia manusia. Hak asasi manusia dengan demikian dimiliki bukan karena diberikan berdasarkan hukum positif, melainkan semata-mata karena eksistensinya sebagai manusia [5]. Dalam arti ini, meskipun setiap orang terlahir dengan warna kulit, jenis kelamin, bahasa, budaya dan kewarganegaraan yang berbeda-beda, ia tetap mempunyai hak-hak tersebut. Dengan demikian, hak asasi manusia mempunyai sifat yang universal. Selain bersifat universal, hakhak itu juga tidak dapat dicabut. Dalam pengertian ini, hak asasi manusia melekat pada dirinya sebagai mahluk insani [6]. Perkara HAM tak sebatas kasus-kasus masa lalu, namun kondisi masyarakat yang kesulitan mengalami persekusi, tidak mendapat akses kesehatan, tidak dapat bersekolah, hingga sulit beribadah adalah pelanggaran HAM dasar yang harus diketahui semua pihak.

Masyarakat sebagai obyek dari penerapan hukum harus memperoleh manfaat dari diberlakukannya hukum. Hukum adalah kumpulan-kumpulan peraturan-peraturan yang 
terdiri dari norma dan sanksi-sanksi itu disebut hukum dan tujuan hukum itu adalah mengadakan ketertiban dalam pergaulan manusia sehingga keamananan dan ketertiban terpelihara [7]. Setiap masyarakat mengharapkan agar hukum itu dapat menciptakan keadilan, ketertiban dan kesejahteraan. Hal ini yang disebut dengan cita hukum yaitu yang berkaitan dengan baik dan buruk, adil atau tidak. Hukum diharapkan mencerminkan nilainilai yang tumbuh dan dirasa adil dalam masyarakat.

Seperangkat hak tersebut tidak dapat diingkari. Pengingkaran terhadap hak tersebut berarti mengingkari martabat kemanusiaan. Oleh karena itu, negara, Pemerintah, atau organisasi apapun mengemban kewajiban, untuk mengakui dan melindungi hak asasi manusia pada setiap manusia tanpa kecuali. Ini berarti bahwa hak asasi manusia harus selalu menjadi titik tolak dan tujuan dalam penyelenggaraan kehidupan bermasyarakat, berbangsa, dan bernegara.

Membina kesadaran hukum adalah suatu tuntutan pembaharuan sosial yang dewasa ini menjadi perhatian pemerintah dan mulai digalakan dalam berbagai usaha pembangunan. Sejak awal pemerintahan Orde Baru secara jelas dan sistematis dituangkan dalam Ketetapan Majelis Permusyawaratan Rakyat (MPR) Nomor IV/MPR/1978 mengenai GarisGaris Besar Haluan (GBHN) dalam hal hukum, tertib hukum dan penegakan hukum. Penegasan hal mi dirumuskan sebagai berikut:

1) pembangunan di bidang hukum didasarkan atas landasan sumber tertib hukum seperti terkandung dalam Pancasila dan Undang-Undang Dasar 1945;

2) guna meningkatkan ketertiban. dan kepastian hukum dalam mengayomi masyarakat, yang merupakan syarat bagi terciptanya stabilitas nasional yang mantap, maka aparatur pemerintah pada umumnya dan aparatur penegak hukum pada khususnya perlu terus menerus dibina dan dikembangkan untuk peningkatan kemampuan serta kewibawaannya;

3) pembangunan dan pembinaan di bidang hukum diarahkan agar hukum mampu memenuhi kebutuhan sesuai dengan tingkat kemajuan pembangunan, sehingga dapat diciptakan ketertiban dan kepastian umum;

4) usaha-usaha penertiban badan-badan penegak hukum perlu dilanjutkan;

5) usaha meningkatkan kemampuan dan kewibawaan aparat penegak hukum perlu dilanjutkan;

6) meningkatkan kesadaran hukum sehingga masyarakat menghayati hak dan kewajibannya;

7) meningkatkan pembinaan sikap para pelaksana penegak hukum ke arah tegaknya hukum, keadilan dan pembinaan Perlindungan harkat dan martabat manusia, ketertiban serta kepastian hukum sesuai dengan Undang-Undang Dasar 1945.

Mengawali pembahasan ini, ada baiknya dijelaskan terlebih dahulu terminologi dari kesadaran hukum. Kesadaran hukum dalam konteks ini berarti kesadaran untuk bertindak sesuai dengan ketentuan hukum. Kesadaran hukum masyarakat merupakan semacam jembatan yang menghubungkan antara peraturan-peraturan hukum dengan tingkah laku hukum anggota masyarakatnya. Lawrence M. Friedman lebih condong menyebutnya sebagai bagian dari kultur hukum, yaitu nilai-nilai, sikap-sikap yang mempengaruhi bekerjanya hukum [8,9]. Pengertian kesadaran hukum menurut para ahli:

a. Krabbe menyatakan bahwa kesadaran hukum merupakan kesadaran atau nilai-nilai yang terdapat di dalam diri manusia, tentang hukum yang ada atau tentang hukum yang diharapkan ada [10].

b. Soerjono soekanto bahwa kesadaran hukum itu merupakan persoalan nilai-nilai yang terdapat pada diri manusia tentang hukum yang ada atau tentang hukum yang diharapakan ada. sebenarnya yang di tekankan adalah nilai-nilai tentang fungsi hukum dan bukan suatu penilaian hukum terhadap kejadian-kejadian yang konkrit dala masyarakat yang bersangkutan [11]. 
c. Paul Scholten yang dimaksud dengan kesadaran hukum adalah kesadaran yang ada pada setiap manusia tentang apa hukum itu atau apa seharusya hukum itu suatu kategori tertentu dari hidup kejiwaan kita dari mana kita membedakan antara hukum (recht) dan tidak hukum (onrecht) antara yang seyogyanya dilakukan dan tidak seyogyanya dilakukan [12].

d. Sudikno Mertokusumo menyatakan bahwa kesadaran hukum berarti kesadaran tentang apa yang seyogyannya kita lakukan atau perbuatan atau yang seyogyannya tidak kita lakukan atau perbuat terutama terhadap orang lain. Ini berarti kesadaran akan kewajiban kita masing-masing terhadap oranglain [13].

Kesadaran hukum merupakan konsepsi abstrak di dalam diri manusia tentang keserasian antara ketertiban dan ketentraman yang dikehendaki.Jadi kesadaran hukum dalam hal ini berarti kesadaran untuk bertindak sesuai dengan ketentuan hukum. Kesadaran hukum dalam masyarakat merupakan semacam jembatan yang menghubungkan antara peraturanperaturan dengan tingkah laku hukum anggota masyarakat.

Secara lebih detail yan Schmid sebagaimana dikutip oleh Sunaryati Hartono, membedakan pengertian antara perasaan hukum dan kesadaran hukum [14]. Untuk menunjukkan letak perbedaan antara kedua istilah itu, Sunaryati Hartono mencoba menjelaskannya dengan menggunakan contoh berikut ini. Di Sulawesi Selatan misalnya, terjadi pembunuhan akibat pemutusan pertunangan yang menimbulkan malu keluarga bakal Pengantin wanita. Demikian pula di Bali, seorang ahli waris yang sah membunuh orang yang membagi-bagikan warisan, karena ia tidak diberi bagian warisan. Penilaian rakyat yang timbul Secara Spontan ini kiranya merupakan "'perasaan hukum" masyarakat. Namun bila hal tersebut dirumuskan dalam pengertian hukum, maka menurut kesadaran hukum masyarakat Bali dan Sulawesi Selatan "Penghinaan berat harus ditebus dengan nyawa". Secara lebih abstrak lagi dapat dikatakan, bahwa kesalahan dan hukuman harus seimbang.

Kesadaran hukum itu bukanlah semata-mata sesuatu yang tumbuh secara spontan dalam hati sanubari masyarkat, akan tetapi ia juga merupakan sesuatu yang harus dipupuk secara sdar, agar dapat tumbuh dalam hati sanubari masyarakat. Von Savigny menjelaskan hal ini dengan mengatakan, isn und wird mit dem volke.

Menurut Prof. Soerjono Soekanto mengemukakan empat indikator kesadaran hukum yang secara beruntun (tahap demi tahap) yaitu [15]:

1. Pengetahuan tentang hukum merupakan pengetahuan seseorang berkenan dengan perilaku tertentu yang diatur oleh hukum tertulis yakni tentang apa yang dilarang dan apa yangdiperbolehkan.

2. Pemahaman tentang hukum adalah sejumlah informasi yang dimiliki oleh seseorang mengenai isi dari aturan (tertulis), yakni mengenai isi, tujuan, dan manfaat dari peraturantersebut.

3. Sikap terhadap hukum adalah suatu kecenderungan untuk menerima atau menolak hukum karena adanya penghargaan atau keinsyafan bahwa hukum tersebut bermanfaat bagi kehidupan manusia dalam hal ini sudah ada elemen apresiasi terhadap aturan hukum.

4. Perilaku hukum adalah tentang berlaku atau tidaknya suatu aturan hukum dalam masyarakat, jika berlaku suatu aturan hukum, sejauh mana berlakunya itu dan sejauh mana masyarakat mematuhinya.

Berkaitan dengan indikator diatas, Otje salman menjelaskan indikator seperti dibawah ini, antara lain [16]:

1. Indikator yang pertama adalah pemahaman tentang hukum, seseorang mengetahui tentang bahwa perilaku-perilaku tertentu itu telah diatur oleh hukum. Peraturan hukum yang dimaksud disini adalah hukum tertulis maupun hukukum yang tidak tertulis, perilaku tersebut menyangkut perilaku yang dilarang oleh hukum maupun perilaku yang diperbolehkan olehhukum. 
2. Indikator yang kedua adalah pemahaman hukum yaitu, sejumlah informasi yang dimiliki seseorang yang mengenai isi peraturan dari suatu hukum ysng tertentu. Pemahaman hukum disini suatu pengertian terhadap isi dan tujuan suatu peraturan dalam hukum tertentu serta manfaatnya bagi pihak-pihak yang kehidupannya diatur oleh peraturan tersebut. Seseorang warga masyarakat mempunyai pengetahuan dan pemahamnnya masing-masing mengenai aturan-aturan tertentu. Misalnya adanya pengetahuan dan pemahaman yang benar mengenai Perda No 7 Tahun 2012 tentang penyelenggaraan ketertiban umum. Khususnyatentangpedagang kaki lima untuk mewujudkan kesadaran hukum dan paham akan hukum tersebut.

3. Indikator yang ketiga adalah sikap hukum, yaitu suatu kecenderungan untuk menerima hukum karena adanya pengghargaan terhadap hukum sebagai sesuatu yang bermanfaat atau mengguntungkan jika hukum tersebut ditaati.seseorang disini yang nantinya akan mempunyai kecenderungan untuk mengadakan penilaian tertentu terhadaphulkum.

4. Indikator yang keempat adalah pola perilaku, yaitu dimana seseorang atau dalam masyarakat warganya mematuhi peraturan yang berlaku. Indikator ini merupakan indikator yang paling utama karena dalam indikator tersebbut dapat dilihat apakah suatu peraturan berlaku atau tidak dalam masyarakat, sehingga seberapa jauh kesadaran hukum dalam masyarakat dapat dilihat dari pola hukum.

Dengan demikian, tegaknya suatu peraturan hukum baru akan menjadi kenyataan bilamana didukung oleh adanya kesadaran hukum dari masyarakat. Kesadaran terhadap berlakunya hukum adalah dasar bagi dilaksanakannya hukum itu sendiri. Semakin merata kesadaran terhadap berlakunya hukum, semakin kecil pula kemungkinan munculnya tingkah laku yang tidak sesuai dengan hukum [17].

Pada dasarnya kesadaran hukum itu merupakan kontrol agar hukum yang telah dibuat itu dapat dijalankan dengan baik di dalam masyarakat. Oleh karena itu, perlu adanya usahausaha untuk menanamkan, mensyaratkan dan melembagakan nilai-nilai yang mendasari peraturan hukum tersebut. Untuk itu perlu diperhatikan masalah komunikasi hukumnya berikut penyebarluasan isi perundang-undangan sehingga dapat diketahui oleh para anggota masyarakat sebagai sasaran pengaturan hukum itu.

Hukum harus dilihat sebagai sub sistem dari suatu sistem yang besar yaitu masyarakat atau lingkungannya. Oleh karena hukum dipandang sebagai suatu sistem, maka untuk memahaminya perlu penggunaan pendekatan sistem. Berbagai penelitian hukum sebagai sistem hukum dikemukakan antara lain oleh Lawrence M. Friedman, bahwa hukum itu terdiri dari komponen struktur, substansi dan kultur [9]:

1. Komponen struktur yaitu kelembagaan yang diciptakan oleh sistem hukum itu dengan berbagai macam fungsi dalam rangka mendukung bekerjanya sistem tersebut. Komponen ini dimungkinkan untuk melihat bagaimana sistem hukum itu memberikan pelayanan terhadap penggarapan bahan-bahan hukum secara teratur.

2. Komponen substantif yaitu sebagai output dari sistem hukum, berupa peraturanperaturan, keputusan-keputusan yang digunakan baik oleh pihak yang mengatur maupun yang diatur.

3. Komponen kultur yaitu terdiri dari nilai-nilai, sikap-sikap, persepsi, custom, ways of doing, ways of thinking, opinion yang mempengaruhi bekerjanya hukum oleh Lawrence M. Friedman disebut sebagai kultur hukum. Kultur hukum inilah yang berfungsi sebagai jembatan yang menghubungkan antara peraturan hukum dengan tingkah laku hukum seluruh warga masyarakat.

Hukum pada umunya diartikan sebagai keseluruhan peraturan atau kaidah dalam kehidupan bersama; keseluruhan tentang tingkah lakuyang berlaku dalam suatu kehidupan bersama, yang dapat dipaksakan pelaksanaannya dengan suatu sanksi [18]. Friedrich Karl von Savigny menyatakan bahwa hukum itu merupakan ekspresi dari kesadaran hukum rakyat (volkgeits). Konsep hukum sebagai sarana berkait dengan perkembangan masyarakat yang didasarkan pada perencanaan, yaitu dengan melakukan pilihan-pilihan 
dari berbagai alternatif untuk mencapai tujuan-tujuan yang diharapkan [17].

Hukum menghendaki agar warga masyarakat bertingkah laku sesuai dengan harapan masyarakat atauu berfungsi sebagai kontrol sosial. Demikian pula hukum berfungsi sarana untuk memperlancar proses interaksi sosial, yaitu dengan memandang hukum sebagai suatu mekanisme kontrol sosial yang bersifat umum dan beroperasi secara merata di hampir seluruh sektor kehidupan masyarakat. Breidemeier menyatakan bahwa fungsi utama suatu sistem hukum bersifat integrative, artinya untuk mengurangi unsur-unsur konflik yang potensial dalam masyarakat, dan untuk melicinkan proses pergaulan sosial [19].

Sudikno Mertokusumo mengatakan bahwa setiap hubungan hukum yang diciptakan oleh hukum selalu mempunyai dua segi yang isinya di satu pihak sebagai hak, sedang di pihak lain kewajiban. Tidak ada hak tanpa kewajiban, sebaliknya tidak ada kewajiban tanpa hak. Hak dan kewajiban menjadi lebih tegas berlaku pada saat hukum dilibatkan dalam kasus konkret. Dengan demikian, implikasinya adalah lahirnya hak dan kewajiban [18].

Pelaksanaan HAM di Indonesia perlu mempertimbangkan realitas nilai-nilai adat istiadat, budaya, dan agama. Selain itu, karena dipandang upaya diseminasi HAM masih berjalan lamban, maka dibutuhkan suatu langkah akseleratif. Saat ini Indonesia telah menetapkan Ranham Indonesia berdasarkan Peraturan Presiden Nomor 75 Tahun 2015 tentang Rencana Aksi Nasional Hak Asasi Manusia Tahun 2015-2019, sebagaimana telah diubah dengan Peraturan Presiden Nomor 33 Tahun 2018.

Salah satu komitmen penting yang dimiliki Indonesia dalam kerangka kebijakan HAM adalah Rencana Aksi Nasional HAM Indonesia (Ranham). Adapun strategi implementasi Ranham berdasar Peraturan Presiden Nomor 75 Tahun 2015meliputi [20]:

1) Penguatan institusi pelaksana Ranham

2) Penyiapan pengesahan dan penyusunan bahan laporan implementasi instrumen internasional HAM

3) Penyiapan regulasi, harmonisasi rancangan peraturan perundang-undangan dan evaluasi peraturan perundang-undangan dari perspektif HAM

4) Pendidikan dan peningkatan kesadaran masyarakat tentang HAM

5) Penerapan norma dan standar HAM

6) Pelayanan komunikasi masyarakat

\section{Metode}

Kegiatan ini akan dilakukan dalam beberapa metode, yaitu sebagai berikut:

1) Ceramah;

2) Diskusi.

Salah satu pendekatan dalam pemecahan permasalahan dalam mendorong budaya sadar hukum adalah pendekatan yang mengacu pada proses pemahaman yang baik terhadap perangkat aturan dan urgennya kesadaran hukum. Masyarakat dan pihak terkait harus lebih memahami Hak Asasi Manusia sehingga akan menumbuhkan sikap saling menghormati Hak Asasi Manusia di kalangan generasi muda. Oleh karena itu, wujud dari kegiatan ini berupa ceramah dan diskusi.

Kegiatan ini merupakan kegiatan dalam rangka mensosialisasikan dan meningkatkan kesadaran hukum masyarakat khususnya generasi muda agar dapat mendorong dan membangun budaya sadar hukum untuk terciptanya kondisi tertib hukum yang sesuai dengan aturan hukum.

Adapun prosedur kerja yang akan dilaksanakan guna merealisasikan solusi dan penggunaan metode, adalah sebagai berikut: 
1) Pemaparan materi mengenai:

a. Definisi dan konsep mengenai Hak Asasi Manusia;

b. Hak Asasi Manusia dalam Undang-Undang Dasar Negara Republik Indonesia Tahun 1945 dan Undang-Undang Nomor 39 Tahun 1999 tentang Hak Asasi Manusia;

c. Fungsi dan tujuan Hak Asasi Manusia dalam kerangka negara hukum.

2) Menampung berbagai keluhan dan persoalan yang dihadapi dalam penerapan Hak Asasi Manusia.

3) Diskusi mengenai upaya yang dapat mendorong peningkatan budaya sadar hukum di kalangan muda.

Pendidikan merupakan jalan menuju kemajuan dalam peningkatan kesadaran dan pengetahuan, salah satunya adalah dengan melakukan sosialisasi, dan diskusi dalam satu forum. Untuk menjawab permasalahan pertama, yakni meningkatan kesadaran hukum generasi muda terhadap Hak Asasi Manusia dalam kerangka negara hukum, maka melalui pendidikan dengan pemaparan secara normatif dan teoritis Hak Asasi Manusia dari perspektif hukum.

Selanjutnya, setelah para peserta memahami Hak Asasi Manusia, maka selanjutnya dilakukan terlebih dahulu pemamparan mengenai pentingnya budaya sadar hukum dalam mencapai tujuan hukum. Hal ini sebagai dasar peserta untuk memahami urgensi meningkatkan budaya sadar hukum. Kemudian, melalui tahapan selanjutnya adalah proses diskusi. Diseminasi ini nantinya akan menghasilkan semakin banyaknya siswa yang peduli dan sadar akan pentingnya budaya sadar hukum.

\section{HASIL DAN PEMBAHASAN}

Berdasarkan data, informasi, dan kenyataan yang ditemui selama melakukan pendekatan sosial dan observasi wilayah menunjukkan bahwa masyarakat yang menjadi khalayak sasaran kegiatan mempunyai pengetahuan dan kesadaran hukum yang masih rendah mengenai Hak Asasi Manusia, sebagian peserta memang ada yang sudah mengetahui dan memahami Hak Asasi Manusia namun banyak juga yang belum mengerti dan memahami Hak Asasi Manusia dalam kerangka negara hukum. Oleh karena itu untuk mengatasi permasalahan tersebut perlu dilakukan suatu kegiatan penyuluhan untuk meningkatkan kesadaran hukum masyarakat terhadap Hak Asasi Manusia guna meningkatkan budaya sadar hukum di kalangan muda.

Kegiatan Penyuluhan Hak Asasi Manusia dalam Mendorong Budaya Sadar Hukum di SMA 5 Bandar Lampung ini dilaksanakan pada tanggal 26 Agustus 2020. Kegiatan ini dihadiri oleh 30 peserta yang terdiri dari siswa/i dan perwakilan guru. Kegiatan ini dilaksanakan secara daring menggunakan media zoom. Pembicara pada kegiatan ini adalah Dosen Fakultas Hukum Unila. Materi Kegiatan yang diberikan bersifat teoretis yang meliputi: Definisi dan konsep mengenai Hak Asasi Manusia; Hak Asasi Manusia dalam Undang-Undang Dasar Negara Republik Indonesia Tahun 1945 dan Undang-Undang Nomor 39 Tahun 1999 tentang Hak Asasi Manusia; Fungsi dan tujuan Hak Asasi Manusia dalam kerangka negara hukum.

Kegiatan yang berlangsung satu hari ini diikuti dengan penuh antusias, perhatian dan tekun dalam menyimak setiap materi yang diberikan. Peserta terkadang memberi tanggapan dan menyampaikan pertanyaan disela-sela pemberian materi, apalagi pada saat diskusi. Hal ini dimungkinkan karena mereka merasa memerlukan materi tersebut. Terlebih adanya realitas bahwa masih rendahnya ketaatan hukum di kalangan muda.

Untuk mengetahui tingkat keberhasilan atau kegagalan kegiatan "penyuluhan hak asasi manusia dalam mendorong budaya sadar hukum" ini, khalayak sasaran kegiatan perlu dilakukan evaluasi. Evaluasi dilakukan secara spesifik untuk mengetahui tingkat penguasaan materi. Langkah-langkah evaluasi dilakukan sebagai berikut: 
a) Evaluasi Awal: dilakukan sebelum penyampaian materi pelatihan, dengan maksud untuk mengetahui tingkat penguasaan materi. Evaluasi ini dilakukan oleh Tim Fasilitator dengan menggunakan daftar pertanyaan (pre-test).

b) Evaluasi Proses: dilakukan selama proses kegiatan pelatihan, dengan cara menilai partisipasi aktif peserta melalui sejumlah pertanyaan dengan bobot pertanyaan yang diajukan.

c) Evaluasi Akhir: dilakukan dengan menggunakan daftar pertanyaan yang sama pada waktu pre-test yang diselenggarakan pada akhir kegiatan. Evaluasi akhir ini bertujuan untuk mengetahui keberhasilan kegiatan pelatihan dengan membandingkan penguasaan materi peserta sebelum dan sesudah kegiatan. Hasil yang dapat dicapai para peserta ditunjukkan dengan melihat perkembangan hasil evaluasi akhir (En) dikurangi hasil evaluasi awal (Ea) atau $\mathrm{K}=(\mathrm{En})$ - (Ea).

Guna menyelesaikan permasalahan sebagaimana telah diuraikan sebelumnya, maka berikut beberapa jenis kepakaran yang dibutuhkan dalam kegiatan ini:

Tabel 1. Jenis Kepakaran yang Diperlukan

\begin{tabular}{cc}
\hline No & Kepakaran \\
\hline 1 & Konstitusi dan Hak Asasi Manusia \\
2 & Ilmu Perundang-Undangan \\
\hline
\end{tabular}

Pre-test dan post-test dilakukan untuk mengukur secara kuantitatif pengetahuan dan kemampuan peserta sehingga dapat dilihat tingkat perubahannya dari sebelum dan setelah dilakukan kegiatan. Hasil pre-test dan post-test dapat dilihat dalam tabel berikut ini:

Tabel 2. Perbandingan Nilai Pretest dan Postest Peserta

\begin{tabular}{|c|c|c|c|c|}
\hline No & Pertanyaan & Hasil Pretest & Hasil Postest & Keterangan \\
\hline 1 & $\begin{array}{l}\text { Apakah Bapak/lbu/Sdr } \\
\text { mengetahui dasar hukum Hak } \\
\text { Asasi Manusia? }\end{array}$ & $\begin{array}{l}45 \% \text { menjawab } \\
\text { tidak tahu }\end{array}$ & $\begin{array}{l}\text { 85\% menjawab } \\
\text { tahu }\end{array}$ & $\begin{array}{l}\text { Sebagian besar peserta } \\
\text { belum mengetahui } \\
\text { dasar hukum Hak Asasi }\end{array}$ \\
\hline 2 & $\begin{array}{l}\text { Apakah Bapak/lbu/Sdr } \\
\text { mengetahui konsep dan } \\
\text { manfaat budaya sadar hukum? }\end{array}$ & $\begin{array}{l}40 \% \text { menjawab } \\
\text { tahu }\end{array}$ & $\begin{array}{l}90 \% \text { menjawab } \\
\text { tahu }\end{array}$ & $\begin{array}{l}\text { Sebagian besar peserta } \\
\text { sudah mengetahui } \\
\text { budaya sadar hukum, } \\
\text { namun masih belum } \\
\text { memahami manfaat dan } \\
\text { urgensinya. }\end{array}$ \\
\hline 3 & $\begin{array}{l}\text { Apakah Bapak/lbu/Sdr } \\
\text { mengetahui produk hukum } \\
\text { daerah apa saja yang telah } \\
\text { ada dalam upaya perlindungan } \\
\text { Hak Asasi Manusia? }\end{array}$ & $\begin{array}{l}90 \% \text { menjawab } \\
\text { tidak tahu }\end{array}$ & $\begin{array}{l}80 \% \text { menjawab } \\
\text { tahu }\end{array}$ & $\begin{array}{l}\text { Sebagian besar peserta } \\
\text { belum mengetahui } \\
\text { bahwa ada Perda yang } \\
\text { melindungi Hak Asasi } \\
\text { Manusia. }\end{array}$ \\
\hline 4 & $\begin{array}{l}\text { Bagaimanakah pendapat } \\
\text { Bapak/lbu/Sdr tentang upaya } \\
\text { pemerintah dalam mendorong } \\
\text { budaya sadar hukum di } \\
\text { kalangan muda? }\end{array}$ & $\begin{array}{l}50 \% \text { menjawab } \\
\text { cukup baik }\end{array}$ & $\begin{array}{l}75 \% \text { menjawab } \\
\text { baik }\end{array}$ & $\begin{array}{l}\text { Sebagian dari peserta } \\
\text { baru menyadari bahwa } \\
\text { Pemerintah telah } \\
\text { berupaya mendorong } \\
\text { budaya sadar hukum di } \\
\text { kalangan muda melalui } \\
\text { berbagai kebijakan. }\end{array}$ \\
\hline 5 & $\begin{array}{l}\text { Menurut Bapak/lbu/Sdr upaya } \\
\text { apa yang harus dilakukan } \\
\text { pemerintah dalam rangka } \\
\text { meningkakan budaya sadar } \\
\text { hukum dikalangan muda agar } \\
\text { lebih baik kedepannya? }\end{array}$ & $\begin{array}{l}80 \% \\
\text { tidak menjawab }\end{array}$ & $\begin{array}{l}60 \% \text { memberi } \\
\text { masukan }\end{array}$ & $\begin{array}{l}\text { Sebagian dari peserta } \\
\text { peduli akan terciptanya } \\
\text { budaya sadar hukum di } \\
\text { kalangan muda }\end{array}$ \\
\hline
\end{tabular}

Berdasarkan hasil pada metode evaluasi ini maka tim menyimpulkan, dengan diketahuinya hasil penyerapan materi oleh peserta sebesar $80 \%$ yang terdiri dari:

1. Pengetahun dasar hukum Hak Asasi Manusia, hasil pretest $45 \%$ peserta menjawab tidak tahu, selanjutnya $85 \%$ peserta menjawab tahu.

2. Pengetahuan tentang konsep dan manfaat budaya sadar hukum, hasil pretest $40 \%$ peserta menjawab tahu, selanjutnya $90 \%$ peserta menjawab tahu. 
3. Pengetahuan produk hukum daerah yang telah ada dalam upaya perlindungan Hak Asasi Manusia, hasil pretest $90 \%$ peserta menjawab tidak tahu, selanjutnya $80 \%$ peserta menjawab tahu.

4. Kepedulian dalam ikut berkontribusi memikirkan upaya yang pemerintah dapat lakukan dalam rangka meningkakan budaya sadar hukum dikalangan muda agar lebih baik, hasil pretest $80 \%$ peserta menjawab tidak menjawab, selanjutnya $60 \%$ peserta masukan.

Keberhasilan pelaksanaan kegiatan ini didukung oleh:

1. Respon Kepala Sekolah SMAN 5 Bandar Lampung yang positif dan mendukung untuk diadakannya kegiatan Penyuluhan Hak Asasi Manusia dalam Mendorong Budaya Sadar Hukum di SMA 5 Bandar Lampung. Mengingat kegiatan ini diharapkan akan mengubah perilaku dan meningkatkan kesadaran peserta untuk saling menghormati dan menghargai Hak Asasmi Manusia yang melekat pada dirinya dan orang lain.

2. Besarnya antusias dan keinginan peserta untuk mengetahui dan memahami Hak Asasi Manusia dan budaya sadar hukum.

3. Adanya bantuan koordinasi oleh para guru kepada para siswa/i sehingga kegiatan ini dapat terlaksana dengan kondusif.

4. Para peserta yang memiliki gadget dan mampu ikut serta dalam video conference sehingga kegiatan yang dilaksanakan secara daring dapat berjalan tanpa hambatan.

Mengingat adanya faktor pendukung di atas, maka dalam pelaksanaan kegiatan ini pada dasarnya tidak ditemui kesulitan yang mendasar.

\section{KESIMPULAN}

Berdasarkan pelaksanaan kegiatan dan pembahasan yang telah dilakukan, dapat disimpulkan bahwa kesadaran hukum masyarakat terhadap Hak Asasi Manusia telah meningkat hingga $80 \%$. Hal ini ditunjukkan dengan beberapa indikator diantaranya: peningkatan pengetahuan terkait dasar hukum Hak Asasi Manusia, konsep dan manfaat budaya sadar hukum, produk hukum daerah yang telah ada dalam upaya perlindungan Hak Asasi Manusia, serta kepedulian dalam ikut berkontribusi memikirkan upaya yang pemerintah dapat lakukan dalam rangka meningkakan budaya sadar hukum dikalangan muda agar lebih baik. Selain itu, kegiatan ini dapat berhasil dengan baik dikarenakan adanya dukungan dari Kepala Sekolah dan guru SMAN 5 Bandar Lampung, serta peserta kegiatan yang antusias dan memberikan respon positif dalam pelaksanaan kegiatan agar kegiatan berjalan lancar.

Minat dan motivasi peserta untuk menggali dan meningkatkan pengetahuan dan pemahamannya dalam rangka meningkatkan kesadaran hukum cukup tinggi. Hasil pelaksanaan kegiatan tersebut peserta menyarankan agar kegiatan semacam ini terus dilaksanakan secara berkesinambungan guna lebih meningkatkan lagi pengetahuan dan pemaha $\neg$ man masyarakat lainnya yang belum mengetahui dan memahami urgensi budaya sadar hukum. Selain itu, diharapkan pada Pemerintah Daerah agar melakukan kerjasama dengan universitas dalam hal pengkajian upaya hukum yang diperlukan dalam mendorong budaya sadar hukum di kalangan generasi muda.

\section{UCAPAN TERIMA KASIH}

Terima kasih disampaikan kepada UNILA yang telah mendanai kegiatan Pengabdian Kepada Masyarakat ini sehingga dapat dilakukan dengan baik atas Hibah Pengabdian Kepada Masyarakat Dipa BLU UNILA Tahun 2020.

\section{DAFTAR PUSTAKA}


[1] https://www.komnasham.go.id/index.php/news/2016/1/8/245/mendorong-kota-ramah-ham-diindonesia.html.

[2] Suseno, Franz Magnis. 2001. Etika Politik: Prinsip-Prinsip Moral Dasar Kenegaraan Modern. Jakarta: PT Gramedia Pustaka Utama.

[3] Huijbers, Theo. 1982. Filsafat Hukum dalam Lintasan Sejarah. Yogyakarta: Kanisius.

[4] Warassih, Esmi. 2011. Pranata Hukum Sebuah Telaah Sosiologis. Semarang. Universitas Diponegoro: Semarang.

[5] Donnely, Jack. 2003. Universal Human Rights in Theory and Practice. New York: Cornell University Press.

[6] Knut D. Asplund, Suparman Marzuki, Eko Riyadi. 2008. Hukum Hak Asasi Manusia. Yogyakarta: PUSHAM UII.

[7] C.S.T. Kansil. 1992. Pengantar Ilmu Hukum dan Tata Hukum Indonesia. Jakarta: Balai Pustaka Indonesia.

[8] Friedman, Lawrence M. 1975. The Legal System. New York: Russell Sage.

[9] Friedman, Lawrence M. 1986. The Legal System: A Social Science Perspective. Newyork: Russel Sage Foundation.

[10] Ali, Achmad., Heryani, Wiwie. 2012. Menjelajahi kajian empiris terhadap hukum. Jakarta: kencana.

[11] Soekanto, Soerjono. 2002. Kesadaran hukum dan kepatuhan hukum. Jakarta: Raja Grafindo Persada.

[12] Mas, Marwan. 2014. Penghantar ilmu hukum. Bogor: Penerbit Ghaila Indonesia.

[13] Mertokusumo, Sudikno. 1981. Menigkatkan Kesadaran Hukum Masyarakat,Edisi Pertama. Yogyakarta: Liberti.

[14] Hartono, Sunaryati. 1975. Peranan Kesadaran Hukum Rakyat Dalam Pembaharuan Hukum. Kertas Kerja pada Symposium Kesadaran Hukum Masyarakat dalam Masa Transisi. Jakarta: BPHN-Bina Cipta.

[15] Soekanto, Soerjono. 1982. Kesadaran dan Kepatuhan Hukum. Jakarta: Rajawali Pers.

[16] Salman, Otje. 1993. Kesadaran Hukum Masyarakat Terhadap Hukum Waris. Bandung: Alumni.

[17] Warassih, Esmi. 2011. Pranata Hukum Sebuah Telaah Sosiologis. Semarang: Badan Penerbitan Universitas Diponegoro.

[18] Mertokusumo, Sudikno. 1986. Mengenal Hukum, Suatu Pengantar. Yogyakarta: Liberti.

[19] Schur, Edwin M. 1968. Law and Society: A Sociological View. New York: Random House.

[20] El Muhtaj, Majda. 2017. Hak Asasi Manusia dalam Konstitusi Indonesia: Dari UUD 1945 sampai dengan Perubahan UUD 1945 Tahun 2002. Jakarta: Kencana. 